\title{
Use of recombinant and synthetic peptides as attachment factors for cells on microcarriers
}

\author{
James Varani, Dennis R. Inman, Suzanne E.G. Fligiel and William J. Hillegas
}

The Department of Pathology, The University of Michigan, Ann Arbor, Michigan; The Department of Pathology, Wayne State University - VAMC, Allen Park, Michigan; SoloHill Labs, Inc., Ann Arbor, Michigan, USA

Received 27 April 1993; accepted in revised form 9 August 1993

Key words: collagen, gelatin, MDCK, microcarrier, polylysine, Pronectin-F

\begin{abstract}
Polystyrene culture dishes and polystyrene microcarriers were coated with Pronectin-F and poly-L-lysine (polylysine), either alone or in combination. Pronectin-F is a recombinant peptide containing repeats of the RGD cell-attachment sequence from fibronectin. Polylysine is a polymer of L-lysine. Pronectin-F supported attachment of Madin-Darby Canine Kidney (MDCK) cells at concentrations as low as $0.025 \mu \mathrm{g} / \mathrm{cm}^{2}$ of surface area. The cells rapidly spread after attachment. Polylysine at concentrations of $0.05-0.5 \mu \mathrm{g} / \mathrm{cm}^{2}$ also supported cell attachment but cells did not rapidly spread after attachment to this substrate. Higher concentrations of polylysine could not be used because of toxicity. When the two peptides were used in conjunction, MDCK cells attached and spread at lower peptide concentrations than they did when either substrate was used alone. These findings suggest that recombinant Pronectin- $F$ alone or in conjunction with a cationic polymer could be a useful replacement for materials such as gelatin or collagen which are currently used as microcarrier surfaces.
\end{abstract}

\section{Introduction}

A number of different materials have proven to be useful as microcarrier substrates for the growth of anchorage-dependent cells (Van Wezel, 1967; Griffiths, Thornton and McEntee, 1982; Varani et al., 1983; Keese and Giaever, 1983; Nielson and Johansson, 1980; Obrenovitch, Maintier and Sene, 1982) and many cell types that grow well in monolayer culture on plastic or glass dishes can be readily adapted to grow on microcarriers. The microcarriers that are the most widely used today contain gelatin or collagen linked either to dextran beads or to polystyrene beads. However, as serumcontaining culture media are replaced with fullysynthetic, serum-free culture media in large-scale operations, it will be important to remove extraneous biologicals from the substrate as well. Further, although many types of cells grow well on collagen- or gelatin-coated polystyrene microcarriers, a number of established cell lines including Madin-Darby canine kidney (MDCK) cells, swine testes cells and Chinese hamster ovary cells do not (unpublished observation). The present study describes the use of combinations of adhesionpromoting recombinant and synthetic peptides (with 
different modes of action) to facilitate cell adhesion to polystyrene microcarriers. The use of peptidecoated polystyrene microcarriers could provide a novel approach to solving the problems associated with currently-available substrates.

\section{Materials and methods}

\section{Substrates}

Polystyrene 24-well culture dishes (Corning Inc.; Corning, NY) and polystyrene plastic microcarriers (Solohill Labs Inc., Ann Arbor, MI) were used in these studies. Both substrates were coated with varying amounts of Pronectin-F (Protein Polymer Technologies Inc., San Diego, CA) and/or poly-Llysine (polylysine), obtained from Sigma Chemical Co. (St. Louis, MO). Pronectin-F is a geneticallyengineered high molecular weight protein polymer incorporating 13 copies of the RGD cell attachment sequence of fibronectin interspersed between structural peptide segments corresponding to the crystalline region of silk. It has a molecular weight of $72 \mathrm{kDa}$. Polylysine is a positively-charged long chain polymer of L-lysine. The preparation used in this study contained peptides of $150-300 \mathrm{kDa}$. Peptides were dissolved in buffer as directed by their respective manufacturers and diluted in phosphate-buffered saline (PBS). Plastic culture dishes were coated with the peptides by incubating the desired amount of each peptide in $0.5 \mathrm{ml}$ of buffer for a 4 -h period. At the end of the incubation period, the nonattached peptide was removed and the dishes incubated for an additional $30 \mathrm{~min}$ with $1 \mathrm{ml}$ of a $10 \mathrm{mg} / \mathrm{ml}$ solution of bovine serum albumin (BSA). The nonattached BSA was then removed and the dishes were washed one time with MEM serum free. At this point, the dishes were ready for use in experiments. (Note: although we did not determine the amount of each peptide that actually bound to the polystyrene dish, we showed in preliminary studies that when a high concentration of polylysine, $(5 \mu \mathrm{g} / 0.5 \mathrm{ml})$ was added to the wells, $69 \%$ bound within $4 \mathrm{~h}$. This was determined by quantifying the nonbound material with the BCA protein reagent (Pierce Chemical Co., Rock- ford, $\Pi$ ) at the end of the incubation. Likewise, when Pronectin-F was added at $5 \mu \mathrm{g} / 0.5 \mathrm{ml}$, we estimated that $42 \%$ bound to the substrate).

Microcarriers were coated in a similar fashion. Five-gram lots were coated by incubating the microcarriers and the desired amount of peptide for $18 \mathrm{~h}$ in a $25 \mathrm{ml}$ volume with constant shaking. After coating, the microcarriers were rinsed two times in PBS and used immediately or stored in PBS for up to several weeks. At the time of use, they were distributed into $35 \mathrm{~mm}$ (diameter) polystyrene culture dishes at a concentration of 50 $\mathrm{mg} /$ dish (approximately $25 \mathrm{~cm}^{2}$ of surface area). Prior to use, the dishes were coated with $1 \mathrm{ml}$ of a $10 \mathrm{mg} / \mathrm{ml}$ solution of BSA. However, the polystyrene microcarriers were not coated with BSA since preliminary studies indicated that cells attached very slowly to the uncoated polystyrene microcarriers in suspension. Experiments were also conducted in 200-ml bulb-stirred culture vessels. For these culture, $25 \mathrm{mg}$ of microcarriers were used per $\mathrm{ml}$.

Assessment of attachment, spreading and proliferation

Madin-Darby Canine Kidney (MDCK) cells were used in these experiments. They were grown in monolayer culture using Minimal Essential Medium of Eagle with Earle's salts (MEM) supplemented with nonessential amino acids, $10 \%$ fetal bovine serum (FBS), $100 \mathrm{U} / \mathrm{ml}$ penicillin and $100 \mu \mathrm{g} / \mathrm{ml}$ streptomcyin as culture medium. Growth was at $37^{\circ} \mathrm{C}$ and $5 \% \mathrm{CO}_{2}$. At the time of assay, the cells were harvested from culture, washed two times in serum-free MEM and resuspended in MEM supplemented with either $0.5 \%$ FBS or $200 \mu \mathrm{g} / \mathrm{ml} \mathrm{BSA}$. For experiments conducted in the 24-well dishes, the cells were added at $1 \times 10^{5}$ cells per dish. The dishes were incubated at $37^{\circ} \mathrm{C}$ and $5 \% \mathrm{CO}_{2}$. At various times, the nonattached cells were removed from duplicate wells. The remaining cells were detached with a solution of trypsin/EDTA $(0.25 \% / 0.05 \%)$ and counted. In parallel dishes, the attached cells were flooded with $2 \%$ glutaraldehyde after removal of the nonattached cells. These dishes were used for estimation of the percentage of cells 
that were spread and for photography. Microcarrier experiments were conducted in 2-ml static cultures and in 200-ml bulb-stirred glass culture vessels. For the small-scale cultures, cells were added at $3 \times 10^{5}$ cells per $\mathrm{ml}$ in MEM supplemented with $0.5 \%$ FBS. The microcarriers and cells were mixed by gentle pipetting and the dishes were then incubated at $37^{\circ} \mathrm{C}$ and $5 \% \quad \mathrm{CO}_{2}$ without additional stirring. After $15 \mathrm{~min}$ the microcarriers with attached cells were aspirated into a tube and allowed to settle. After removal of the culture medium containing the nonattached cells, the microcarriers with cells attached were resuspended, washed and exposed to $0.1 \mathrm{~N}$ citric acid. The lysed cells were counted using a nuclei assay (Sanford et al., 1951) with the aid of a hemocytometer. The 200-ml culture experiments were conducted in a similar fashion except that the cells $\left(1.5 \times 10^{5} / \mathrm{ml}\right)$ and microcarriers $(25 \mathrm{mg} / \mathrm{ml})$ were kept in suspension by continual stirring (approximately $22 \mathrm{rpm}$ ).

\section{Cytotoxicity assay}

Cytotoxicity was assessed using a ${ }^{51} \mathrm{Cr}$-release assay (Varani et al., 1985). MDCK cells were cultured for one day in a $75 \mathrm{~cm}^{2}$ flask in the presence of $25 \mu \mathrm{Ci}$ of $\mathrm{Na}_{2}{ }^{51} \mathrm{CrO}_{4}$. The radio-labelled cells were then harvested, washed and added to uncoated culture dishes or dishes coated with varying concentrations of Pronectin-F and/or polylysine. The culture dishes were incubated at $37^{\circ} \mathrm{C}$ and $5 \% \mathrm{CO}_{2}$. Eighteen hours later, the supernatant fluids were collected from all wells and analyzed for cell-free radioactivity. The cells remaining attached to the substrate were lysed in a $1 \%$ solution of Triton X-100 detergent and the radioactivity associated with the detergent-lysed cells was also determined. The cell-free radioactivity recovered from the supernatant fluids was expressed as a percentage of the total radioactivity. After subtraction of the radioactivity released from cells' incubated on uncoated dishes, the percentage of radioactivity specifically released on each of the experimental substrates was determined.
Enzyme-linked immunosorbant assay (ELISA) for laminin

An ELISA was used to quantify the amount of immunoreactive laminin present in the culture fluids of the cells. Cells were added to appropriately coated plastic culture dishes as described above and incubated for $18 \mathrm{~h}$. MEM supplemented with $0.5 \%$ FBS was used as culture medium. At the end of the incubation period, the culture fluids were separated from the cells and microcarriers and clarified by low speed centrifugation. One hundred $\mu l$ were added to wells of a 96-well plate (Falcon Plastics, Oxnard, CA) from lots that had been preselected for acceptability in ELISAs. The culture fluids were incubated in the wells for $3 \mathrm{~h}$ at $37^{\circ} \mathrm{C}$. Control culture medium which had been preincubated along with the cells served as a control. Purified laminin from the murine EHS tumor (0.5-0.0005 $\mu \mathrm{g} /$ well) (Collaborative Research, Boston MA) was incubated in the same medium to serve as a standard. After the $3 \mathrm{~h}$ incubation, the supernatant fluids were removed from the wells. The wells were washed three times and the ELISA carried out as described previously (Varani et al., 1989).

An ELISA was also used to assess lamininbinding to the various substrates. For this, wells of a 24-well dish were coated with pronectin-F and/or polylysine (and BSA) as described above. Following this, exogenous laminin from the EHS sarcoma (Collaborative Research, Boston, MA) $(50 \mu \mathrm{g} / \mathrm{well})$ was added in MEM supplemented with $0.5 \%$ FBS. After incubation for $4 \mathrm{~h}$ at $37^{\circ} \mathrm{C}$, the nonbound laminin was removed and quantified by ELISA.

\section{Results}

Effects of Pronectin- $F$ and polylysine on attachment and growth of MDCK cells on polystyrene plastic culture dishes

In the first experiment, varying amounts of Pronectin- $F$ and polylysine were coated onto the surface of plastic culture dishes. Up to $10 \mu \mathrm{g}$ of each agent was used per well. ${ }^{51} \mathrm{Cr}$-labelled MDCK 
cells were then added to the dishes in MEM supplemented with $0.5 \%$ FBS and toxicity assessed after $18 \mathrm{~h}$. With Pronectin-F, concentrations as high as $10 \mu \mathrm{g} /$ well showed no evidence of toxicity. In contrast, when polylysine was coated onto culture dishes under the same conditions, toxicity was seen at concentrations above $1 \mu \mathrm{g} /$ well (not shown).

Based on the results of the toxicity assays, the two peptides were examined for ability to induce attachment of MDCK cells. Table 1 shows results from a series of experiments in which the two peptides were used singly and in combination. It can be seen that both peptides induced attachment of MDCK cells. With Pronectin-F, concentrations as low as $0.025 \mu \mathrm{g} / \mathrm{cm}^{2}$ were effective. With polylysine, concentrations between 0.05 and $0.5 \mu \mathrm{g} / \mathrm{cm}^{2}$ were effective. It can also be seen in Table 1 that although both peptides induced attachment of the MDCK cells, only Pronectin-F induced spreading. In addition to examining the two peptides singly, they were also used in combination. As can be seen in Table 1, the two peptides together were more effective than when either was used singly. In particular, it should be noted that when the two peptides were used in combination, Pronectin- $\mathrm{F}$ at $0.005 \mu \mathrm{g} / \mathrm{cm}^{2}$ and polylysine at $0.05 \mu \mathrm{g} / \mathrm{cm}^{2}$ in duced virtually maximal attachment and spreading. The data shown in Table 1 was obtained in serum (0.5\% FBS)-containing medium. Virtually identical results were obtained in medium supplemented with $200 \mu \mathrm{g} / \mathrm{ml} \mathrm{BSA}$ in place of serum. Serum-containing medium was used for the majority of our studies since the particular strain of MDCK cells used did not proliferate under serum-free conditions without adaptation.

In the next series of experiments, cells were examined for growth on polystyrene culture dishes coated with Pronectin-F and/or polylysine. Duplicate 24-well culture dishes were used and cells were added exactly as in the attachment assay. One

Table 1. Attachment of MDCK cells to polystyrene culture dishes coated with combinations of Pronectin-F and polylysine

\begin{tabular}{lrl}
\hline Surface treatment $\left(\mu \mathrm{g} / \mathrm{cm}^{2}\right)^{\mathbf{a}}$ & Attachment $\left(\text { Number of cells } \times 10^{-3}\right)^{\mathbf{b}}$ & Spreading (percent) $^{\mathrm{c}}$ \\
\hline None & $33 \pm 1$ & $<5$ \\
$0.5 \mu \mathrm{g}$ Polylysine & $102 \pm 1$ & $<5$ \\
$0.25 \mu \mathrm{g}$ Polylysine & $89 \pm 2$ & $<5$ \\
$0.05 \mu \mathrm{g}$ polylysine & $42 \pm 1$ & $<5$ \\
& $72 \pm 2$ & $27 \pm 6$ \\
$0.025 \mu \mathrm{g}$ Pronectin-F & $116 \pm 3$ & $17 \pm 8$ \\
$+0.5 \mu \mathrm{g}$ Polylysine & $124 \pm 6$ & $26 \pm 2$ \\
$+0.25 \mu \mathrm{g}$ Polylysine & $97 \pm 1$ & $33 \pm 3$ \\
$+0.05 \mu \mathrm{g}$ Polylysine & & \\
& $42 \pm 2$ & $20 \pm 8$ \\
$0.005 \mu \mathrm{g}$ Pronectin-F & $105 \pm 2$ & $18 \pm 2$ \\
$+0.5 \mu \mathrm{g}$ Polylysine & $106 \pm 4$ & $27 \pm 3$ \\
$+0.25 \mu \mathrm{g}$ Polylysine & $91 \pm 10$ & $20 \pm 4$ \\
$+0.05 \mu \mathrm{g}$ Polylysine & & 2 \\
\hline
\end{tabular}

${ }^{a}$ Wells of a $24-$ well polystyrene culture dish were coated with Pronectin-F and/or polylysine by incubating the reagent in the well for $4 \mathrm{~h}$ at $37^{\circ} \mathrm{C}$ in a total volume of $0.5 \mathrm{ml}$. At the end of the incubation period, the non-bound reagent was removed and $1 \mathrm{ml}$ of a $10 \mathrm{mg} / \mathrm{ml}$ solution of BSA was added. Control wells (none) were also coated with the BSA solution. This was removed after 30 $\min$.

${ }^{b}$ MDCK cells $\left(1 \times 10^{5} /\right.$ well) were added in MEM supplemented with $0.5 \%$ FBS and incubated for 15 minutes. At the end of the incubation period, the nonattached cells were removed. The attached cells were dislodged with trypsin/EDTA and counted. The values shown represent averages \pm differences between individual values and averages based on duplicate samples in a single experiment. The experiment was repeated three times with similar results.

${ }^{c}$ MDCK cells $\left(1 \times 10^{5} /\right.$ well $)$ were added in MEM supplemented with $0.5 \%$ FBS and incubated for 30 minutes. At the end of the incubation period, the nonattached cells were removed and discarded. The dishes were flooded with $2 \%$ glutaraldehyde and spreading was assessed microscopically. The values shown represent the average percent spread \pm standard deviations based on four separate readings in each of duplicate dishes in a single experiment. The experiment was repeated three times with similar results. 
dish was harvested and counted at the 15-min time point. In the other dish, nonattached cells were removed at the same time point. The dish with attached cells still in place was washed two times and then reincubated for $18 \mathrm{~h}$. The cells from this group were harvested and counted after the 18-h incubation. Table 2 shows a strong correlation between initial attachment and cell growth. Those substrates which had the most cells attached (15 min time point) also showed the greatest increase in cell numbers over the $18 \mathrm{~h}$ incubation period. At the upper end, there was a virtual doubling of the cells. On those substrates to which fewer cells initially attached, there was also less cell growth over the 18-h time course. It can be seen from Table 2 that on the uncoated polystyrene wells, where the fewest cells attached to begin with, there was essentially no growth over the 18-h time period. We attribute the lack of growth in the control group to the fact that with so few cells present initially, the cells were not able to rapidly condition the culture medium.

\section{Production of Laminin by MDCK cells grown on plastic culture dishes coated with Pronectin- $F$ and/or polylysine}

Laminin was assayed in the culture fluid of MDCK cells grown on the various peptide-coated culture dishes. Cells were added to the dishes in the normal manner and incubated for $18 \mathrm{~h}$. At the end of the incubation period, culture fluids were analyzed as described in the Materials and Methods. After removal of the supernatant fluid, the remaining cells were harvested and counted. As can be seen in Table 3 , there was a slightly increased

Table 2. Growth of MDCK cells on polystyrene culture dishes coated with combinations of Pronectin-F and polylysine

\begin{tabular}{|c|c|c|}
\hline \multirow[b]{2}{*}{ Surface treatment $\left(\mu \mathrm{g} / \mathrm{cm}^{2}\right)^{\mathrm{a}}$} & \multicolumn{2}{|c|}{ Attachment (number of cells $\times 10^{-3}$ ) } \\
\hline & $15 \min ^{b}$ & $18 h^{c}$ \\
\hline None & $30 \pm 5$ & $22 \pm 9$ \\
\hline $0.5 \mu \mathrm{g}$ Polylysine & $113 \pm 11$ & $204 \pm 20$ \\
\hline $0.25 \mu \mathrm{g}$ Polylysine & $90 \pm 7$ & $214 \pm 18$ \\
\hline $0.05 \mu \mathrm{g}$ Polylysine & $40 \pm 2$ & $68 \pm 7$ \\
\hline $0.025 \mu \mathrm{g}$ Pronectin-F & $75 \pm 5$ & $105 \pm 12$ \\
\hline$+0.5 \mu \mathrm{g}$ Polylysine & $121 \pm 8$ & $224 \pm 6$ \\
\hline$+0.25 \mu \mathrm{g}$ Polylysine & $125 \pm 4$ & $219 \pm 4$ \\
\hline$+0.05 \mu \mathrm{g}$ Polylysine & $95 \pm 5$ & $167 \pm 7$ \\
\hline $0.005 \mu \mathrm{g}$ Pronectin-F & $40 \pm 3$ & $71 \pm 4$ \\
\hline$+0.5 \mu \mathrm{g}$ Polylysine & $102 \pm 8$ & $239 \pm 5$ \\
\hline$+0.25 \mu \mathrm{g}$ Polylysine & $106 \pm 4$ & $224 \pm 14$ \\
\hline$+0.05 \mu \mathrm{g}$ Polylysine & $99 \pm 7$ & $202 \pm 16$ \\
\hline
\end{tabular}

${ }^{a}$ Wells of a $24-w e l l$ polystyrene culture dish were coated with Pronectin- $F$ and/or polylysine by incubating the reagent in the well for $4 \mathrm{~h}$ at $37^{\circ} \mathrm{C}$ in a total volume of $0.5 \mathrm{ml}$. At the end of the incubation period, the nonbound reagent was removed and $1 \mathrm{ml}$ of a $10 \mathrm{mg} / \mathrm{ml}$ solution of BSA was added. Control wells (none) were also coated with the BSA solution. This was removed after 30 $\min$.

${ }^{\mathrm{b}}$ MDCK cells $\left(1 \times 10^{5} /\right.$ well) were added in MEM supplemented with $0.5 \%$ FBS and incubated for 15 min. At the end of the incubation period, the nonattached cells were removed. The attached cells were dislodged with trypsin/EDTA and counted. The values shown represent averages \pm differences between individual values and averages based on duplicate samples in a single experiment. The experiment was repeated two times with similar results.

${ }^{c}$ MDCK cells $\left(1 \times 10^{5} /\right.$ well) were added in MEM supplemented with $0.5 \%$ FBS and incubated for 15 min. At the end of the incubation period, the nonattached cells were removed. The attached cells were washed two times and incubated for an additional $18 \mathrm{~h}$ in MEM-supplemented with $0.5 \%$ FBS. At the end of the second incubation period, the cells were dislodged with trypsin/EDTA and counted. The values shown represent averages \pm differences between individual values and averages based on duplicate samples in a single experiment. The experiment was repeated two times with similar results. 
Table 3. Immunoreactive laminin in culture fluids of MDCK cells grown on polystyrene culture dishes coated with combinations of Pronectin-F and polylysine

\begin{tabular}{lc}
\hline Surface treatment $\left(\mu \mathrm{g} / \mathrm{cm}^{2}\right)^{\mathrm{a}}$ & Laminin $(\mathrm{ng} / 100 \mu \mathrm{l})^{\mathrm{b}}$ \\
\hline None & $13 \pm 5$ \\
$0.5 \mu \mathrm{g}$ polylysine & $2 \pm 1$ \\
$0.25 \mu \mathrm{g}$ polylysine & $2 \pm 2$ \\
$0.05 \mu \mathrm{g}$ polylysine & $1 \pm 1$ \\
& $12 \pm 1$ \\
$0.025 \mu \mathrm{g}$ Pronectin-F & $4 \pm 1$ \\
$+0.5 \mu \mathrm{g}$ polylysine & $5 \pm 1$ \\
$+0.25 \mu \mathrm{g}$ polylysine & $4 \pm 1$ \\
$+0.05 \mu \mathrm{g}$ polylysine & $18 \pm 2$ \\
& $4 \pm 1$ \\
$0.005 \mu \mathrm{g}$ Pronectin-F & $7 \pm 2$ \\
$+0.5 \mu \mathrm{g}$ polylysine & $5 \pm 1$ \\
$+0.25 \mu \mathrm{g}$ polylysine & \\
$+0.05 \mu \mathrm{g}$ polylysine &
\end{tabular}

${ }^{a}$ Wells were coated Pronectin-F and/or polylysine exactly as described in the legend to Table 1 . Cells $\left(1 \times 10^{5}\right)$ were added to the wells in MEM supplemented with $0.5 \%$ FBS. Culture fluids were collected after $18 \mathrm{~h}$ of incubation and analyzed for immunoreactive laminin by ELISA. Cells were harvested and counted.

${ }^{b}$ Values represent averages \pm differences between individual values and averages based on duplicate samples in a single experiment. The experiment was repeated three times with similar results.

amount of laminin in the culture fluid from the cells grown on Pronectin-F as compared to the untreated controls. In contrast, there was a significant decrease in laminin production by cells grown on the polylysine-coated dishes. A decrease was also observed in the culture fluid of the cells grown on dishes coated with both Pronectin-F and polylysine. The decreased laminin detected in the culture fluid of the cells grown in the presence of polylysine was not due to laminin binding to the polylysine. This was shown by adding exogenous laminin to the substrate and then quantifying the amount remaining in solution $4 \mathrm{~h}$ later. When this was done, $89-94 \%$ of the amount recovered from the control dishes was recovered from the polylysine-coated dishes.

Attachment of MDCK cells to polystyrene microcarriers coated with Pronectin-F and/or polylysine

A final series of experiments were carried out to determine if the two peptides would influence MDCK cell attachment to polystyrene microcarriers. Microcarriers were coated with the same concentrations of the two peptides as the cultures dishes. Table 4 shows the results of attachment studies in both the small-scale (2-ml) cultures and the 200-ml cultures. It can be seen that the two peptides induced cell attachment as compared to controls. It can also be seen from the small-scale cultures that there was greater attachment to the microcarriers coated with the two peptides in combination than to microcarriers coated with either one alone. Thus, the data obtained on the microcarriers followed the same trends as the data obtained on plastic culture dishes. Figure 1 shows photographs of cells on uncoated polystyrene microcarriers and microcarriers coated with a combination of Pronectin-F and polylysine after 15 min of incubation.

\section{Discussion}

A number of materials are capable of supporting cell growth in microcarrier culture. Included are dextran covalently linked to various charged moieties, dextran covalently bonded to collagen, polystyrene plastic, polystyrene plastic sputtercoated with a layer of glass and polystyrene plastic linked noncovalently to collagen or gelatin (van Wezel, 1967; Nielson and Johansson, 1980; Varani 
Table 4. Attachment of MDCK cells to polystyrene microcarriers coated with combinations of Pronectin-F and polylysine

\begin{tabular}{lc}
\hline Surface treatment $\left(\mu \mathrm{g} / \mathrm{cm}^{2}\right)$ & Attachment $\left(\text { number of cells } \times 10^{-3}\right)^{\mathrm{b}}$ \\
\hline $2 m l$ cultures & $6 \pm 1$ \\
None & $244 \pm 29$ \\
$0.5 \mu \mathrm{g}$ Polylysine & $81 \pm 23$ \\
$0.25 \mu \mathrm{g}$ Polylysine & $25 \pm 18$ \\
$0.025 \mu \mathrm{g}$ Pronectin-F & $292 \pm 17$ \\
$+0.5 \mu \mathrm{g}$ Polylysine & $161 \pm 15$ \\
$+0.25 \mu \mathrm{g}$ Polylysine & $18 \pm 9$ \\
$0.005 \mu \mathrm{g}$ Pronectin-F & $294 \pm 63$ \\
$+0.5 \mu \mathrm{g}$ Polylysine & $200 \pm 43$ \\
$+0.25 \mu \mathrm{g}$ Polylysine & \\
$200-m l$ cultures & \\
None & $60 \pm 13$ \\
$0.025 \mu \mathrm{g}$ Polylysine & $20 \pm 24$ \\
$0.005 \mu \mathrm{g}$ Pronectin-F & $55 \pm 12$ \\
$+0.25 \mu \mathrm{g}$ Polylysine & \\
\hline
\end{tabular}

${ }^{a}$ Polystyrene microcarriers were coated with Pronectin-F and polylysine alone and in combination. MDCK cells ( $3 \times 10^{5} / \mathrm{culture}$ dish) were added in MEM supplemented with 0.5\% FBS. The cells and substrate were incubated together for 15 min. Following this, the nonattached cells were removed and discarded. The attached cells were released with trypsin/EDTA and counted. Values represent the average number of cells that were attached \pm standard deviations based on four separate readings from each of duplicate dishes in three separate experiments combined.

${ }^{b}$ The $200-\mathrm{ml}$ culture experiments were carried out exactly as the $2-\mathrm{ml}$ culture experiments except that cells $\left(1.5 \times 10^{5} / \mathrm{ml}\right)$ and microcarriers were stirred continually during the $15 \mathrm{~min}$ incubation period. Values represent the average number of cells that were attached \pm standard deviation based on 10 separate readings from each $200-\mathrm{ml}$ culture vessel in a single experiment. The experiment was repeated two times.

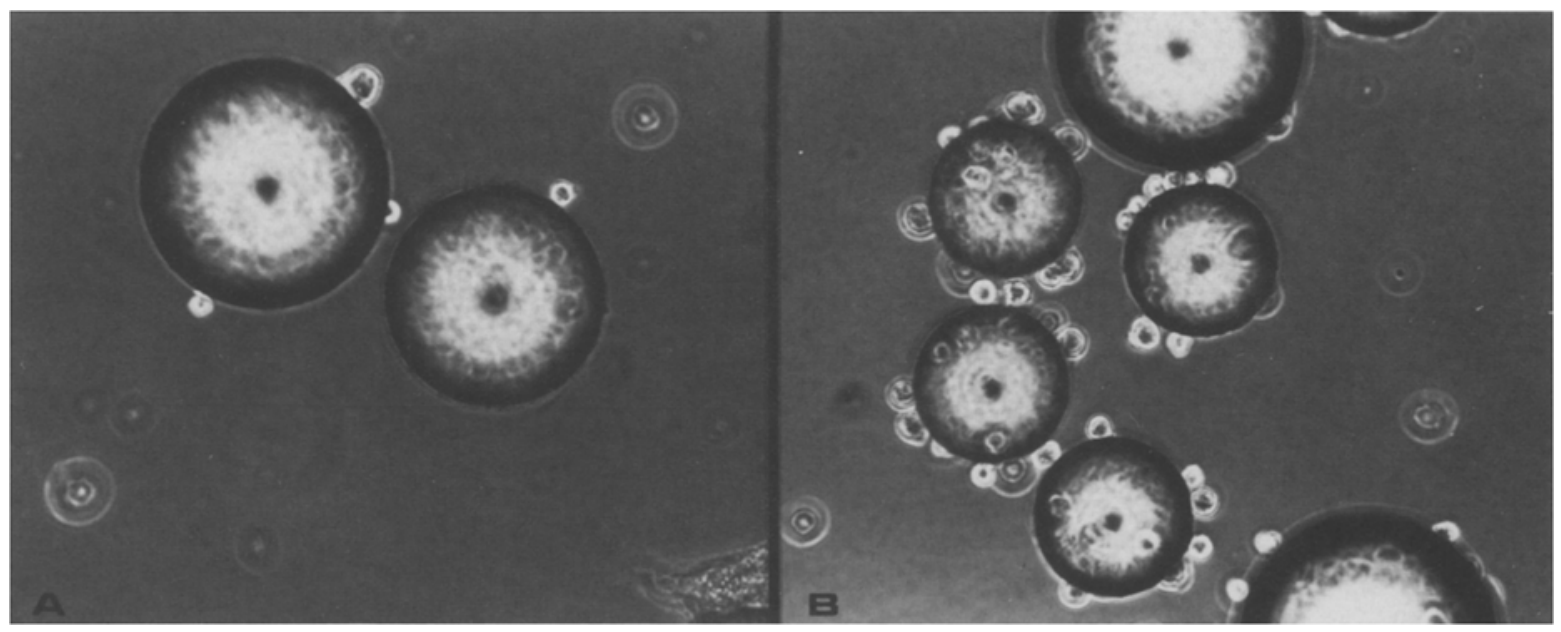

Fig. 1. A. Phase-contrast photomicrograph showing few MDCK cells attached to uncoated polystyrene microcarriers 15 min after addition; B. Phase contrast photomicrograph showing many MDCK cells attached to polystyrene microcarriers coated with $0.005 \mu \mathrm{g}$ of Pronectin-F and $0.25 \mu \mathrm{g}$ of polylysine per $\mathrm{cm}^{2}(\times 200)$. 
et al., 1983; Varani et al., 1989). Other materials that have been successfully used as microcarriers include acrylamide, liquid fluorocarbons, alginate, cellulose and solid gelatin (Obrenovitch et al., 1982; Keese and Giaever, 1983; Larsson and Litwin, 1987). Although certain of the presentlyavailable microcarriers are being utilized in viral production processes (Griffiths et al., 1982; van Wezel and van Steenis, 1978; Spier and Whiteside, 1976; Mered, 1981; Widell, Hansson and Nordenfelt, 1984; Scattergood, 1983; Fiorentine, Shahar and Mizrahi, 1985; Larsson and Litwin, 1987; Pay, 1985; Hoffman and Palmer, 1990), there is a need for the development of new microcarrier products with additional capabilities. At least two factors are providing impetus for new development. First is the need to remove uncharacterized biologicals from manufacturing processes. As completely synthetic culture media replace serum-containing media, it will be imperative to eliminate extraneous biologicals from the substrate as well. Second, although many types of commercially-important cells grow well on existing microcarrier substrates, others do not. In particular, a number of established cell lines with inherently low adhesive capacity do not effectively attach to the substrate under conditions of high shear-stress in bioreactors.

In the present report, we describe a novel approach to the development of microcarrier products with enhanced capacity to support cell attachment. Here we have used recombinant and fully synthetic adhesion-supporting peptides as the active surface ligands. The peptides used include Pronectin-F, a recombinant peptide containing repeats of the RGD cell-attachment sequence from fibronectin, and polylysine, a highly cationic polymer of L-lysine. The RGD tripeptide is the minimal sequence of amino acids recognized by the fibronectin receptor present on most mammalian cells (Ruoslahti and Pierschbacher, 1986). Even among transformed cells which have significantly reduced fibronectin receptor expression, there is strong adhesion to this amino acid sequence (Plantefaber and Hynes, 1989). The present studies showed that Pronectin-F was capable of supporting attachment of cells to either polystyrene dishes or polystyrene microcarriers at concentrations as low
$0.025 \mu \mathrm{g} / \mathrm{cm}^{2}$ of surface area. Further, the cells rapidly spread on this substrate after attachment and underwent proliferation. Thus, Pronectin-F, by itself, would appear to be an ideal surface coating for microcarriers. We envision the use of PronectinF-coated microcarriers in manufacturing operations that now utilize collagen- or gelatin-coated microcarriers but which are moving toward a fully synthetic process. Additionally, Pronectin-F-coated polystyrene microcarriers might be very useful in culture systems employing intrinsically low-adhesive transformed cells. Whether $0.025 \mu \mathrm{g} / \mathrm{cm}^{2}$ proves optimal for use with microcarriers will require further study. It appears from our data that the efficiency of cell attachment is reduced on microcarriers relative to the flat, plastic culture dishes at both Pronectin-F concentrations. Perhaps a higher concentration of Pronectin-F on the microcarriers would increase attachment but this would also increase overall cost. The polycationic peptide, polylysine, was also used as a potential substrate in these studies. Polycations such as polylysine bind tightly to anionic substances on the surface of cells. When polycations are adsorbed onto a solid surface, they promote a rapid and solid attachment of cells to the substrate (Ginsburg, 1987). In addition to promoting cell-substrate attachment, polycations promote cell-cell adhesion, phagocytosis and, in neutrophils, activation of the respiratory burst (Ginsburg, 1987). Our studies showed that polylysine would support cell attachment to polystyrene microcarriers and polystyrene culture dishes. However, there was a high degree of toxicity with this agent at the concentrations which were most effective at promoting attachment (above 0.5 $\mu \mathrm{g} / \mathrm{cm}^{2}$ ). At subtoxic concentrations, attachmentpromoting activity fell off, although concentrations were identified which were not toxic but which would still support attachment over that seen on bare polystyrene alone. These data suggest that it might be possible to use polylysine as an attachment factor but it is unlikely to provide a significant advantage over materials that are presently available for this purpose.

Although it does not appear that polylysine will provide dramatic benefits as a microcarrier coating by itself, the incorporation of both Pronectin-F and 
polylysine onto the microcarrier surface could provide significant advantages over microcarriers coated with either peptide alone. Our studies showed that there was enhanced attachment of MDCK cells to both polystyrene dishes and polystyrene microcarriers coated with a combination of the two peptides as compared to that seen with either peptide alone. Of particular interest, the addition of polylysine along with the Pronectin-F reduced the concentration of Pronectin-F needed for an optimal response. Since the cost of the peptides will ultimately be one determinant of the utility of this approach for large-scale manufacturing operations, the ability to reduce the requirement for Pronectin-F will help to make this approach feasible. Further, the amount of polylysine needed for a significant effect in combination with Pronectin- $F$ was $0.05 \mu \mathrm{g} / \mathrm{cm}^{2}$ of surface area and this was at least a 10-fold lower concentration than concentrations which were cytotoxic. How the two peptides function in concert to promote cell attachment is not fully understood. A reasonable suggestion is that the positively-charged peptide serves to attract cells to the substrate and that once attracted, the cells interact with Pronectin-F through specific cell surface receptors for RGD-containing adhesion factors. It has been shown that interaction of cell surface adhesion receptors with their ligands not only binds cells to the substrate, it also results in cell "activation" (Schwartz, 1993). This leads to the rearrangement of cell surface and cytoskeletal proteins that are necessary for spreading and to the activation of genes involved in proliferation.

Biosynthesis of laminin and incorporation of the newly-synthesized laminin in the pericellular matrix is one of the events in the proliferative response of epithelial cells (Frenette et al., 1988). Our past studies have shown that when human squamous epithelial cells were grown on modified DEAEdextran (modified by incorporation of positively charged groups), laminin production was greatly inhibited as compared to when the same cells were grown on other substrates (Varani et al., 1989). This resulted in a temporary retardation of cell spreading, even though the cells rapidly attached. The present findings show that the same inhibition of laminin production occurs on cationic substrates such as polylysine. It may be that the failure of cells to synthesize sufficient amounts of laminin when grown on charged surfaces is causally related to the failure to become fully activated on the same surfaces. The presence of Pronectin-F may act in part, therefore, by providing an alternate substrate on which this critical event can take place. Whether this is correct or not will require further study. Regardless, it appears that secretion of immunoreactive laminin into the culture fluid is a good indicator of the capacity of a substrate to support not only attachment but rapid spreading as well.

\section{Acknowledgements}

This study was supported by grant CA58154 from the USPHS.

\section{References}

Fiorentine D, Shahar A and Mizrahi A (1985) Production of herpes virus of turkeys in a microcarrier culturing system a new method for production of vaccine against Marek's disease. Dev. Biol. Standard 60: 421-430.

Frenette GP, Carey TE, Varani J, Schwartz DR, Fligiel SEG, Ruddon RW and Peters BP (1988) Biosynthesis and secretion of laminin and laminin-associated glycoproteins by nonmalignant and malignant keratinocytes: comparison of cell lines from primary and secondary tumors in the same patient. Cancer Res. 48: 5193-5204.

Giard D (1977) Virus production with a newly developed microcarrier system. Applied. Environ. Microbiol. 34: 668672 .

Ginsburg I (1987) Cationic polyelectrolytes: a new look at their possible roles as opsinins, as stimulators of the respiratory burst in leukocytes, in bacteriolysis and as modulators of immune complex disease. Inflammation 11: 489-515.

Griffiths JB, Thornton B and McEntee I (1982) The development and use of microcarrier and glass sphere culture techniques for the production of herpes simplex virus. Dev. Biol. Standard 50: 103-110.

Hoffman $T$ and Palmer S (1990) Alternative Matrices for the Growth of BHK-21 cells and the production of rubella virus. In Vitro 26: 55A.

Keese $C$ and Giaever I (1983) Cell growth on liquid microcarriers. Science 219: 144-1449.

Larsson B and Litwin J (1987) The growth of polio virus in human diploid fibroblasts grown with cellulose microcarriers in suspension cultures. Dev. Biol. Standard 66: 385- 390.

Mered B (1981) Propagation of poliovirus in microcarrier 
cultures of three monkey kidney cell lines. J. Biol. Standard 9: 137-145.

Nielson V. and Johansson I (1980) Biosilon; optimal culture conditions and various research scale culture techniques. Dev. Biol. Standard 46: 131-136.

Obrenovitch A, Maintier C and Sene C (1982) Microcarrier culture of fibroblastic cells on modified trisacryl beads. Biol. Cell 46: 249-256.

Pay TWF (1985) Production of rabies vaccine by an industrial scale BHK 21 suspension cell culture process. Dev. Biol. Standard 60: 171-174.

Plantefaber LC and Hynes RO (1989) Changes in integrin receptors on oncogenically transformed cells. Cell 56: 281290.

Ruoslahti E and Pierschbacher MD (1986) Arg-Gly-Asp: a versatile cell recognition signal. Cell 44: 517-518.

Schwartz MA (1993) Signaling by integrins: implications for tumorigenesis. Cancer Res. 53: 1503-1506.

Spier RE and Whiteside JP (1976) The production of foot and mouth disease virus from BHK $21 \mathrm{C} 13$ cells grown on the surface of DEAE sephadex A50 beads. Biotech. Bioeng. 28: 659-667.

Scattergood EM (1983) Scale-up of chick cell growth on microcarriers in fermenters for vaccine production. Ann. N.Y. Acad. Sci. 413: 332-339. van Wezel AL (1967) Growth of cell strains and primary cells on microcarriers. Nature 216: 65-66.

van Wezel AL and van Steenis G (1978) Production of an inactivated rabies vaccine in primary dog kidney cells. Dev. Biol. Standard 40: 69-75.

Varani J, Dame M, Beals TF and Wass JA (1983) Growth of three established cell lines on glass microcarriers. Biotech. Bioeng. 25: 1359-1372.

Varani J, Fligiel SEG, Till GO, Kunkel RG, Ryan US and Ward PA (1985) Pulmonary endothelial cell killing by human neutrophils. Possible involvement of hydroxyl radical. Lab. Invest. 53: 656-663.

Varani J, Fligiel SEG, Inman DR, Helmreich DL, Bendelow MJ and Hillegas W (1989) Substrate-dependent differences in production of extracellular matrix molecules by squamous carcinoma cells and diploid fibroblasts. Biotech. Bioeng. 33: 1235-1241.

Widell A, Hansson BG and Nordenfelt E (1984) A microcarrier cell culture system for large scale production of hepatitis a virus. J. Virolog. Meth. 8: 63-71.

Address for correspondence: James Varani, Department of Pathology, The University of Michigan Medical School, 1301 Catherine Rd / Box 0602, Ann Arbor, MI 48109, USA, 